\title{
Dog parasite incidence and risk factors, from sampling after one-year interval, in Pinhais, Brazil
}

\author{
Incidência e fatores de risco de parasitas de cães, amostragem após um ano, Pinhais, Brasil \\ Camila Marinelli Martins ${ }^{1}$; Cristiane da Conceição de Barros²; Daniele Bier ${ }^{1}$; Ana Paula Marinho'; \\ Jaqueline Maria Gonçalves Figueiredo' ${ }^{1}$; Juliano Leônidas Hoffmann³ \\ Marcelo Beltrão Molento ${ }^{1}$; Alexander Welker Biondo, ${ }^{1,4 *}$
}

${ }^{1}$ Department of Veterinary Medicine, Federal University of Paraná - UFPR, Curitiba, PR, Brasil

${ }^{2}$ Department of Health Surveillance, Municipal Health Department, Pinhais, PR, Brasil

${ }^{3}$ Field Epidemiology Training Program - FETP/Brazil - EPISUS, Center for Strategic Information and Response in Health Surveillance, Department of Epidemiological Surveillance, Secretariat of Health Surveillance, Ministry of Health, Brasilia, DF, Brasil

${ }^{4}$ Department of Veterinary Pathobiology, University of Illinois, Illinois, IL, USA

Received June 27, 2011

Accepted February 14, 2012

\begin{abstract}
Domestic animals in urban areas may serve as reservoirs for parasitic zoonoses. The aim of this study was to monitor the parasitic status of household dogs in an urban area of Pinhais, in the metropolitan region of Curitiba, Paraná State, Brazil, after a one-year period. In May 2009, fecal samples, skin scrapings and ticks were collected from 171 dogs. Questionnaires were applied to the owners (sex, age, environment and anthelmintic use). In May 2010, 26.3\% (45/171) of the dogs were fecal samples reanalysed. From the fecal samples, 33.3\% (57/171) in 2009 and 64.4\% (29/45) in 2010 were positive. The parasite species most observed were, respectively in 2009 and 2010, Ancylostoma sp., 66.7 and 44.8\%, and Strongyloides stercoralis, 26.3 and 3.4\%. All the skin scrapings were negative, and no ticks or protozoa were found. There was no statistical association ( $\mathrm{p}>0.05)$ between positive fecal tests and age, sex or environment. In 2009 alone, dogs with a history of antiparasitic drug administration were 2.3 times more likely to be negative. A great number of replacement dogs was noticed one year later. Therefore, isolated antiparasitic treatment strategies may have no impact on parasite control, given the risk of introduction of new agents, thereby limiting the prevention strategies.
\end{abstract}

Keywords: Dog, parasitism, helminth, public health, zoonosis.

\section{Resumo}

Animais domésticos em áreas urbanas podem servir de reservatório para zoonoses parasitárias. O objetivo deste trabalho foi monitorar a situação parasitária de cães domiciliados, após um ano, em área urbana de Pinhais, região metropolitana de Curitiba, Estado do Paraná, Brasil. Em maio de 2009, foram coletadas amostras de fezes de 171 cães, realizados raspados cutâneos e pesquisa de carrapatos. Foi aplicado um questionário aos proprietários (sexo, idade, ambiente e uso de vermífugos). Em maio de 2010, 26,3\% (45/171) dos cães tiveram as amostras de fezes analisadas novamente. Das amostras de fezes, 33,3\% (57/171) em 2009 e 64,4\% (29/45) em 2010, foram positivas. As espécies de parasitos mais frequentes em 2009 e 2010 foram, respectivamente, Ancylostoma sp. 66,7 e 44,8\% e Strongyloides stercoralis, 26,3 e 3,4\%. Todos os raspados cutâneos foram negativos e nenhum carrapato ou protozoário foi encontrado. Não houve associaçáo estatística $(\mathrm{p}>0.05)$ entre exame positivo e idade, sexo ou ambiente. Somente em 2009, cães com histórico de antiparasitários tiveram 2,3 vezes mais chance de serem negativos. Foi observada grande substituição dos cáes após um ano. Dessa forma, estratégias isoladas de tratamento podem obter efeito nulo quanto ao controle de parasitas, haja vista o risco de introdução de novos agentes, limitando estratégias de prevenção dos mesmos.

Palavras-chave: Cão, parasitismo, helminto, saúde pública, zoonoses.

\footnotetext{
${ }^{*}$ Corresponding author: Alexander Welker Biondo

Departamento de Medicina Veterinária, Universidade Federal do Paraná - UFPR,

Rua dos Funcionários, 1540, Juvevê, CEP 80035-050, Curitiba, PR, Brasil

e-mail: abiondo@ufpr.br
} 


\section{Introduction}

The excessive number of owned dogs hosting intestinal parasites that have access to the streets in Brazilian urban areas may expose local communities to contaminated feces in public areas (Robertson et al., 2000). This has been reported as a risk factor for zoonotic infections (CAPUANO; ROCHA, 2005). Dog endoparasites with occasional human infection include Toxocara canis and Ancylostoma sp., which are the causative agents of visceral and cutaneous larva migrans, respectively (BÄCHLI et al., 2004), and Cryptosporidium parvum, Giardia lamblia and Dipylidium caninum, which may cause gastrointestinal disorders (OLIVEIRA-SEQUEIRA et al., 2002).

Several studies conducted worldwide on dog endoparasites have shown varying results. The rate of infection ranged from 2.4 to $33.2 \%(9.8 \pm 13.1 \%)$ to Ancylostoma sp. and 0.7 to $33.6 \%$ $(11.5 \pm 11.4 \%)$ to Toxocara sp. In surveys conducted in Australia, Switzerland, Italy, Spain and Greece (NABAIS, 2008). Trichuris vulpis infection was found to range from 15 to $20 \%$ in the United States (BLAGBURN et al., 1996). In South America, a few studies in Colombia, Venezuela, Argentina and Chile have shown similar widely ranging results (NABAIS, 2008; FONTANARROSA et al., 2006; LÓPEZ et al., 2006), with Ancylostoma spp. infection ranging from 1.8 to $61.1 \%(22.4 \pm 26.3 \%)$ and Toxocara spp. from 2.5 to $55 \%(19.9 \pm 23.7 \%)$.

A review performed by a study in Brazil verified the status of fecal parasitism in dogs in several cities in the southern region (Porto Alegre and Londrina) and the southeastern region (Viçosa, Uberlândia, São Paulo, Araçatuba, Espírito Santo do Pinhal, Botucatu and Monte Negro) (LABRUNA et al., 2006). The highest frequency observed in this study was for Ancylostoma spp. infection, ranging from 13.5 to $79.1 \%$, followed by Toxocara spp., from 5.5 to $39.0 \%$, Trichuris vulpis, from 0.0 to $70.0 \%$, and Dipylidium caninum, from 0.0 to $8.3 \%$. Another, other studies were conducted in the central-western region (Goiânia), southern region (Itapema, Porto Alegre, Curitiba and Rio Grande) and southeastern region (Praia Grande and Lavras), showing Ancylostoma spp. infection ranging from 9.2 to $93.7 \%$, followed by Trichuris vulpis, from 3.25 to $32.5 \%$, Toxocara spp., from 1.2 to $23 \%$, and Dipylidium caninum, from 0.26 to $1.9 \%$ (SCAINI et al., 2003; LEITE et al., 2004; ALVES et al., 2005; BLAZIUS et al., 2005; CASTRO et al., 2005; GUIMARÃES et al., 2005; LORENZINI et al., 2007).

All these previous studies were conducted on single-sample prevalence of endoparasites in different dog populations. However, no survey has previously been conducted on parasitism within the same dog population over time. Accordingly, the aim of the present study was to monitor the parasitic status of dogs after a one-year interval in an urban area of Pinhais, in the metropolitan region of Curitiba, southern Brazil.

\section{Material and Methods}

The survey for the present study was conducted over a two-day period in May 2009 and again in May 2010, in the Bonilauri neighborhood of the Alto Tarumá district, city of Pinhais. The city is located at latitude $25^{\circ} 26^{\prime} 41^{\prime \prime}$ and longitude $49^{\circ} 11^{\prime} 33^{\prime \prime}$, and is in the western part of the metropolitan region of Curitiba (Figure 1). Pinhais has 112,852 inhabitants (IBGE, 2010), and its human development index (HDI) is 0.815 . This study received technical and official support from the Zoonosis Control Center (ZCC) of Pinhais and the fieldwork was done by 60 volunteers and ZCC personnel. Since the study was approved by the city's Health Department as part of its yearly activities, dog owners were officially informed house-to-house by health agents and were encouraged to participate in the survey.

The Bonilauri neighborhood is a homogeneous settlement of resource-poor people distributed in 380 households and was chosen as the study area. The area has an estimated population of 826 people and 297 dogs, with a dog-to-human ratio of 1:2.78 (PAMPUCH, 2008, personal communication). The number of sampled animals with $5 \%$ confidence level ( $\mathrm{p}<0.05$ ) was 168 dogs (FLEISS, 1981). The houses were divided according to the number of blocks/streets and number of houses per square meter, to ensure homogeneous spatial distribution.

Permission forms were handed out to dog owners, who signed them before animal sampling was done. A questionnaire was used to obtain household and animal information (sex, age, street access, characteristics of the dog's living place and whether the dogs had been given antiparasitic drugs at least once). The information was stratified according to sex, age (up to year of age or over one year), street access (yes or no), quality of the dog's living place (excellent, good, regular or poor) and antiparasitic treatment (yes or no). All available animals belonging to the household underwent fecal sampling, skin scraping and tick collection. The sampling procedures were performed similarly in 2010, when the same animals were sought, based on the original registration forms.

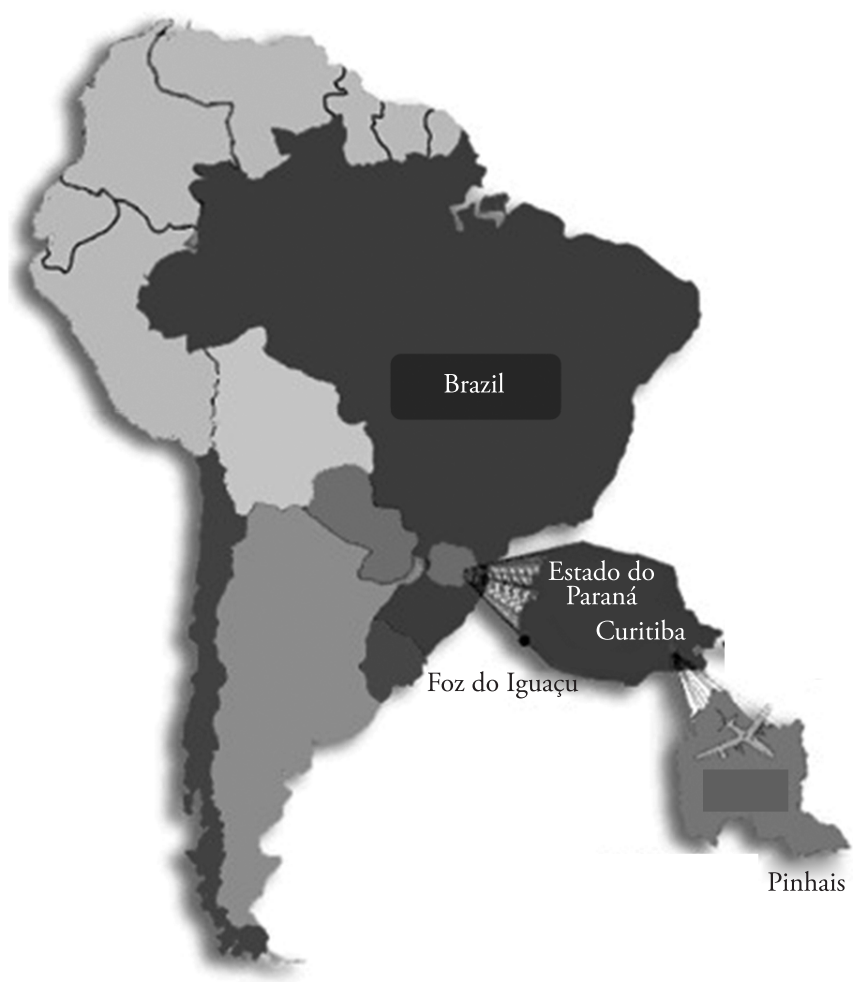

Figure 1. Map of South America and the location of the cities of Pinhais and Curitiba, state of Paraná, Brazil. 
Fecal samples were collected directly from the dogs' rectal ampulla and around $1 \mathrm{~g}$ of feces was placed into a commercial transportation tube containing 9\% formalin (Paratest ${ }^{\oplus}$, Diagnostek, São Paulo, Brazil). Parasite eggs were observed under an optical microscope and were identified in accordance with standard techniques (MONTEIRO, 2011). All the animals were examined for the presence of ticks and skin lesions and skin scrapings were placed into a glass tube for further analysis.

\section{Statistical analysis}

The results were analysed with Epi-info (Epi-Info version 3.5.2, Centers for Diseases Control and Prevention, Atlanta, USA). The odds ratio was calculated for each parameter, and descriptive and chi-square analyses were performed at a confidence level of 5\% $(\mathrm{p}<0.05)$. Maps were created using the ArcView software.

\section{Results}

Out of the total number of fecal samples obtained in 2009, $57 / 171(33.3 \%)$ was positive for at least one parasite. Among the parasites, $66.7 \%$ were identified as Ancylostoma spp., $26.3 \%$ as Strongyloides stercoralis, $14.1 \%$ as Trichuris vulpis and $10.5 \%$ as Toxocara canis. When coinfection was evaluated, $86 \%$ was found to be infected with only one, $8.8 \%$ with two and $5.3 \%$ with three helminth species simultaneously (Table 1). In 2010, 64.4\% were positive for at least one parasite, and $58.6 \%$ of the samples were identified as positive for Toxocara canis, $44.8 \%$ for Ancylostoma spp.,

Table 1. Results stratified according to the dogs' sex, age, street access, living place and antiparasitic treatment, including positive and negative results from 2009 and 2010, in the Bonilauri area of Pinhais, Brazil.

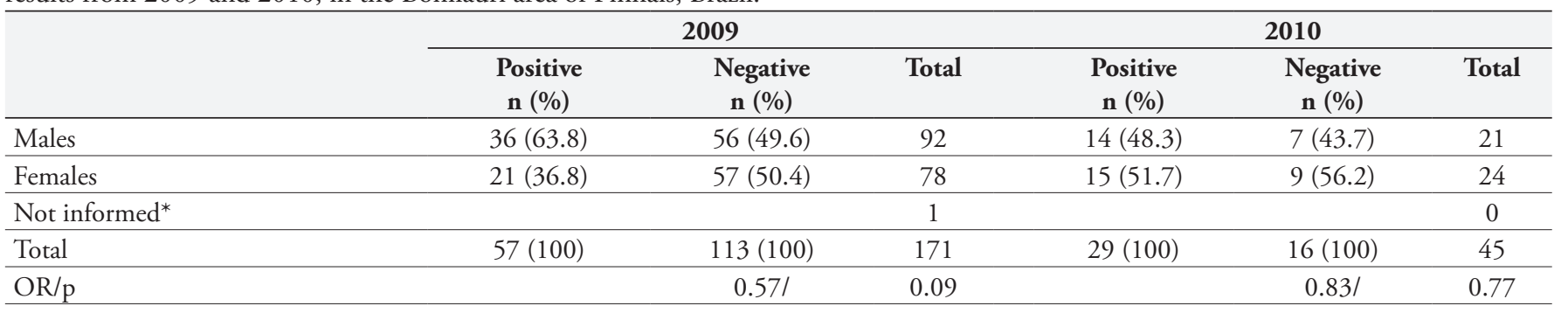

Age

\begin{tabular}{|c|c|c|c|c|c|c|}
\hline Up to one year & $19(35.2)$ & $23(23.2)$ & 42 & $5(19.2)$ & $1(6.2)$ & 6 \\
\hline Over one year & $35(65.8)$ & $76(76.7)$ & 111 & $21(80.1)$ & $15(93.7)$ & 36 \\
\hline Not informed* & & & 19 & & & 3 \\
\hline Total & $54(100.0)$ & $99(100.0)$ & 171 & $26(100.0)$ & $16(100.0)$ & 45 \\
\hline $\mathrm{OR} / \mathrm{p}$ & & $0.56 /$ & 0.11 & & $0.28 /$ & 0.24 \\
\hline
\end{tabular}

\begin{tabular}{|c|c|c|c|c|c|c|}
\hline Street access & & & & & & \\
\hline Yes & $24(42.1)$ & $41(36.3)$ & 45 & $10(38.5)$ & $7(43.7)$ & 17 \\
\hline No & $33(57.9)$ & $72(63.7)$ & 105 & $16(61.5)$ & $9(56.2)$ & 25 \\
\hline Not informed* & & & 21 & & & 3 \\
\hline Total & $57(100.0)$ & $113(100.0)$ & 171 & $26(100.0)$ & $16(100.0)$ & 45 \\
\hline $\mathrm{OR} / \mathrm{p}$ & & $0.78 /$ & 0.46 & & $1.24 /$ & 0.73 \\
\hline
\end{tabular}

\begin{tabular}{|c|c|c|c|c|c|c|}
\hline Living place & & & & & & \\
\hline Excellent and good & $22(40.7)$ & $42(38.2)$ & 64 & $10(35.7)$ & $7(46.6)$ & 17 \\
\hline Regular and poor & $32(59.2)$ & $68(61.8)$ & 100 & $18(64.3)$ & $8(53.3)$ & 26 \\
\hline Not informed* & & & 7 & & & 2 \\
\hline Total & $54(100.0)$ & $110(100.0)$ & 171 & $28(100.0)$ & $15(100.0)$ & 45 \\
\hline $\mathrm{OR} / \mathrm{p}$ & & $0.89 /$ & 0.75 & & $1.57 /$ & 0.48 \\
\hline \multicolumn{7}{|l|}{ Antiparasitic drugs } \\
\hline Treated & $24(43.6)$ & $70(64.2)$ & 94 & $19(42,2)$ & $11(24,4)$ & 30 \\
\hline Not treated & $31(56.4)$ & $39(35.8)$ & 70 & $7(15.5)$ & $5(11.1)$ & 12 \\
\hline Not informed* & & & 7 & & & 3 \\
\hline Total & $55(100.0)$ & $109(100.0)$ & 171 & $26(100.0)$ & $16(100.0)$ & 45 \\
\hline $\mathrm{OR} / \mathrm{p}$ & & $2.31 /$ & 0.01 & & $0.81 /$ & 0.76 \\
\hline Comparative between years & & 1 & & & $2.66 /$ & 0.24 \\
\hline
\end{tabular}

$\mathrm{n}=$ number of samples; ${ }^{*}$ data not informed were not taken into consideration; $\mathrm{OR}=$ odds ratio; $\mathrm{p}=$ statistical significance at $5 \%$ level. 
10.3\% for Toxascaris spp., 6.9\% for Trichuris vulpis and 6.9\% for Dipylidium caninum. A total of $21 / 29$ animals (72.4\%) were infected with only one parasite, $24.2 \%$ with two and $3.4 \%$ with three species simultaneously.

No protozoan parasites were found in the samples, at either sampling time. Skin scrapings were obtained from 30 dogs in 2009 and 7 dogs in 2010, and all the results were negative. No ticks were found at either sampling time.

The information regarding gender, age, outdoor access and living conditions were not statically significantly different between the positive and negative animals. Males and females were equally likely to be negative in 2009 , and although there was a tendency for males to be more infected $(p=0.09)$, no significant difference was found. Similarly, no gender differences were observed in 2010 ( $p=0.77$ ). In addition, no differences between endoparasites were found for any age $(\mathrm{p}=0.11$ and 0.24$)$, for outdoor access $(\mathrm{p}=0.46$ and 0.73$)$ or for living place $(\mathrm{p}=0.75$ and 0.48$)$, in 2009 and 2010 respectively. Dogs that were infected in 2009 had a similar tendency to be infected in 2010 ( $p=0.24)$, but dogs with no history of anthelmintic treatment in 2009 were statistically different $(p=0.01)$ and 2.3 times more likely to be infected than were treated animals (Table 1 ).

Out of the sampled households, 34.6\% in 2009 and $67.6 \%$ in 2010 presented at least one dog with endoparasites. The positive and negative dogs per household in the 2009 and 2010 samplings are presented in Figure 2. A total of 171 dogs from 150 households were successfully sampled in 2009, but only 45 (26.3\%) of the same dogs, from 37 households, were found in 2010 based on the previous registrations. The main reason for not finding the 126 animals that were missing in 2010 were as follows: dogs whose owners were not present at the house (30.2\%); inadequate or

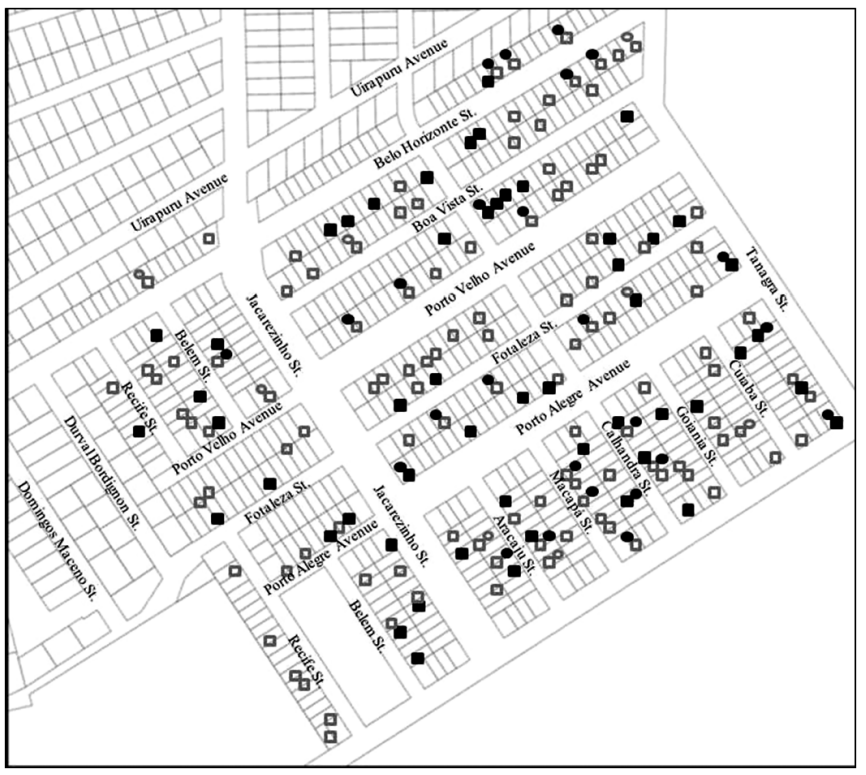

Figure 2. Description of the Bonilauri area and the locations at which dogs were sampled for parasitological tests in 2009 and 2010. Filled squares correspond to positive animals in 2009 and empty squares correspond to negative animals in 2009 Filled circles correspond to positive animals in 2010 and empty circles correspond to negative animals in 2010 . insufficient sample obtained (21.4\%); dog deaths (17.5\%); dogs with no signed permission (15.1\%); owners who had moved out of the neighborhood (9.5\%), lost dogs (8.7\%), aggressive dogs $(8.7 \%)$; and donated dogs $(4.8 \%)$.

\section{Discussion and Conclusion}

The high rate of infected dogs at the two sampling times is within the range found in previous studies in different regions of Brazil (LEITE et al., 2004; ALVES et al., 2005; BLAZIUS et al., 2005; LORENZINI et al., 2007). Ancylostoma spp. was also one of the most prevalent parasite species in previous studies (LORENZINI et al., 2007; LEITE et al., 2004; CASTRO et al., 2005; GUIMARÁES et al., 2005; BLAZIUS et al., 2005). The second most prevalent parasite found in 2009 was Strongyloides stercoralis. This result is different from most of the results found in the literature in Brazil (LEITE et al., 2004; ALVES et al., 2005; BLAZIUS et al., 2005; LORENZINI et al., 2007), but the same as in a study in the city of Rio Grande (SCAINI et al., 2003). Trichuris vulpis eggs were found in both 2009 and 2010, and similar results were observed in São Paulo (OLIVEIRA-SEQUEIRA et al., 2002), Santa Catarina (BLAZIUS et al., 2005) and Curitiba (LEITE et al., 2004). Toxocara canis was the main helminth found in 2010, corresponding to $58.6 \%$ of the number of eggs found. However, other studies in Brazil have indicated widely ranging lower prevalence for this parasite, from 1 to $11 \%$ (OLIVEIRA-SEQUEIRA et al., 2002; SCAINI et al., 2003; LEITE et al., 2004; ALVES et al., 2005; BLAZIUS et al., 2005; CASTRO et al., 2005; LORENZINI et al., 2007). Only a single study has demonstrated similar prevalence, of 70\% (GUIMARÁES et al., 2005).

No protozoan parasites were found at either sampling time, thus differing from other studies in Brazil that have detected protozoa. Giardia sp., Cystoisospora sp., Sarcocystis sp. and Cryptosporidium parvum have been the protozoa most frequently found (OLIVEIRA-SEQUEIRA et al., 2002; LEITE et al., 2004; ALVES et al., 2005; BLAZIUS et al., 2005; LORENZINI et al., 2007). Our data may reflect the low number of these parasites in this area and the environmental effect of the fall season. No animals presented diarrhea.

In urban areas, the most frequent tick species is Rhipicephalus sanguineus (RIBEIRO et al., 1997). The absence of adult ticks on the animals of the present study may have been due to the seasonality of this species, since the study was conducted in late fall, a period when $R$. sanguineus could be in the larval or nymph stages (SOUZA, 2008), living in small cracks in concrete or wood surfaces (DIPEOLU, 1982). Although fleas and lice are important regarding transmission of zoonotic diseases, only a small number of fleas (Ctenocephalides sp.) and no lice were found in the dogs of the present study.

Host characteristics relating to parasite burden, including gender, age, street access, living place and antiparasitic treatment, are still a matter of major controversy. Some studies, similarly to the present one, have not found any statistical significance or tendencies, either for males or for females (ALVES et al., 2005; LABRUNA et al., 2006). However, males had higher parasite burden in another study (FONTANARROSA et al., 2006). Most 
other studies have shown that dogs younger than one year of age are more likely to be parasitized (OLIVEIRA-SEQUEIRA et al., 2002; ALVES et al., 2005; FONTANARROSA et al., 2006; LORENZINI et al., 2007), although a single previous study showed that there was no statistical difference regarding age, similarly to the present study (LABRUNA et al., 2006). We consider that this factor may be dependent on the intensity of parasite infection and the local conditions for the animals.

To the present authors' knowledge, only a single study has compared street access as a risk factor for parasite burden (LABRUNA et al., 2006). That study presents results similar to those of the present study, thus showing that both the indoor and the outdoor environments may have been contaminated with viable parasite eggs in these urban areas (CHAVES et al., 2006; PRADO et al., 2001).

A history of antiparasitic drug administration may be a significant single protection factor, as previously published (XAVIER, 2006), thus indicating that periodic use of anthelmintics may cause a reduction in helminth frequency in dogs (JORDAN et al., 1993; BUGG, 1999). To the present authors' knowledge, no study has previously been conducted on the same animals over a period of time. However, the same dogs in this área were found only $26.3 \%$ in 2010 , while the other $73.7 \%$ were no found or had died or moved. Although this situation was accounted for through using a questionnaire at the beginning of the survey, the high turnover rate among the dogs in this area was surprising. The high death rate $(17.5 \%)$ may reflects the short life expectancy of dogs in resource-poor areas, and we consider that any intervention will only be successful when the strategies focus on educating owners to take responsible care of their animals.

In conclusion, we have demonstrated that programs that monitor animal health status are effective, and that even dogs that did not have street access can become reinfected with parasite species that are important from a public health point of view. Annual application of antiparasitic drugs may not be sufficiently effective for parasite eradication, with regard to both the parasitic and the free-living stages, but it may significantly lengthen the time taken for reinfection to become established, thus leading to a safer environment. In addition, the high turnover among the dogs in this area may reflect an attitude towards human and animal health that is of great concern, since it may cause an influx of new pathogens that can harm local communities.

\section{References}

Alves OF, Gomes AG, Silva AC. Ocorrência de enteroparasitos em cães do município de Goiânia, Goiás: Comparação de técnicas de diagnóstico. Cienc Anim Bras 2005; 6(2): 127-133.

Bächli H, Minet JC, Gratzl O. Cerebral toxocariasis: a possible cause of epileptic seizure in children. Child Nerv Syst 2004; 20(7): 468-472. PMid:15138789.

Blagburn BL, Lindsay DS, Vaughan JL, Rippey NS, Wright JC, Lynn $\mathrm{RC}$, et al. Prevalence of canine parasites based on fecal ?otation. Comp Contin Educ Vet Pract 1996; 18: 483-509.

Blazius RD, Emerick S, Prophiro JS, Romão PRT, Silva OS. Ocorrência de protozoários e helmintos em amostras de fezes de cães errantes da Cidade de Itapema, Santa Catarina. Rev Soc Bras Med Trop 2005; 38(1): 73-74. PMid:15717103. http://dx.doi.org/10.1590/ S0037-86822005000100018

Bugg RJ, Robertson ID, Elliot AD, Thompson RCA. Gastrointestinal parasites of urban dogs in Perth, Western Australia. Vet J 1999; 157(3): 295-301. PMid:10328840. http://dx.doi.org/10.1053/ tvjl.1998.0327

Capuano DM, Rocha GM. Environmental contamination by Toxocara sp. Eggs in Ribeirão Preto, São Paulo state, Brazil. Rev Inst Med Trop São Paulo 2005; 47(4): 223-226. http://dx.doi.org/10.1590/ S0036-46652005000400009

Castro JM, Santos SV, Monteiro NA. Contaminação de canteiros da orla marítima do Município de Praia Grande, São Paulo, por ovos de Ancylostoma e Toxocara em fezes de cães. Rev Soc Bras Med Trop 2005; 38(2): 199-201. PMid:15821802. http://dx.doi.org/10.1590/ S0037-86822005000200017

Chaves EMS, Vazquez L, Lopes K, Flores J, Oliveira L, Rizzi L, et al. Levantamento de Protozoonoses e Verminoses nas sete creches municipais de Uruguaiana, Rio Grande do Sul - Brasil. RBAC 2006; 38(1): 39-41.

Dipeolu OO, Akinboade AO, Ogunji FO. Observations on the epidemiology of house infesting Rhipicephalus sanguineus in a household in Lagos, Nigeria. Bull Anim Health Prod Afr 1982; 30(1): 29-30. PMid:7186809.

Fleiss JL. Statistical Methods for rates and proportions. Wiley-Interscience; $1981.414 \mathrm{p}$.

Fontanarrosa MF, Vezzani D, Basabe J, Eiras DF. An epidemiological study of gastrointestinal parasites of dogs from Southern Greater Buenos Aires (Argentina): age, gender, breed, mixed infections, and seasonal and spatial patterns. Vet Parasitol 2006; 136(3-4): 283-95. PMid:16364551. http://dx.doi.org/10.1016/j.vetpar.2005.11.012

Guimarães AM, Alves EG, De Rezende GF, Rodrigues MC. Ovos de Toxocara sp. e larvas de Ancylostoma sp. em praça pública de Lavras, MG. Rev Saúde Pública 2005; 39(2): 293-295. PMid:15895151.

Instituto Brasileiro de Geografia e Estatística - IBGE. Censo 2010 Paraná [online]. 2010 [cited 2011 Feb. 04]. Available from: http:// www.ibge.com.br/home/estatistica/populacao/censo2010/tabelas_pdf/ total_populacao_parana.pdf.

Jordan HE, Mullins ST, Stebbins ME. Endoparasitism in dogs: 21,583 cases (1981-1990). J Am Vet Med Assoc 1993; 203(4): 547-549. PMid:8407513.

Labruna MB, Pena HFJ, Souza SLP, Pinter A, Silva JCR, Ragozo AMA, et al. Prevalência de endoparasitas em cães da área urbana do município de Monte Negro, Rondônia. Arq Inst Biol 2006; 73(2): 183-193.

Leite LC, Marinoni LP, Círio SM, Diniz JMF, Silva MAN, Luz E, et al. Endoparasitas em cães (Canis familiaris) na cidade de Curitiba, Paraná, Brasil. Arch Vet Sci 2004; 9(2): 95-99.

López JD, Abarca KV, Paredes PM, Inzunza ET. Intestinal parasites in dogs and cats with gastrointestinal symptoms in Santiago, Chile. Rev Méd Chil 2006; 134(2): 193-200. PMid:16554927.

Lorenzini G, Tasca T, Carli, GA. Prevalence of intestinal parasites in dogs and cats under veterinary care in Porto Alegre, Rio Grande do Sul, Brazil. Braz J Vet Res Anim Sci 2007; 44(2): 137-145.

Monteiro SG. Parasitologia na Medicina Veterinária. Editora Roca; 2011. 
Nabais PMMD. Controlo de helmintoses gastrointestinais em cães [Dissertação]. Lisboa: Faculdade de Medicina Veterinária de Lisboa; 2008.

Oliveira-Sequeira TCG, Amarante AF, Ferrari TB, Nunes LC. Prevalence of intestinal parasites in dogs from São Paulo State, Brazil. Vet Parasitol 2002; 103(1-2): 19-27. http://dx.doi.org/10.1016/ S0304-4017(01)00575-1

Prado MS, Barreto ML, Strina A, Faria JA, Nobre AA, Jesus SR. Prevalence and intensity of infection by intestinal parasites in school-aged children in the City of Salvador (Bahia, Brazil). Rev Soc Bras Med Trop 2001; 34(1): 99-101. PMid:11340505.

Ribeiro VLS, Weber MA, Fetzer LO, Vargas CRB. Espécies e prevalência das infestações por carrapatos em cães de rua da cidade de Porto Alegre, RS, Brasil. Cienc Rural 1997; 27(2): 285-289. http://dx.doi.org/10.1590/ S0103-84781997000200019
Robertson ID, Irwin PJ, Lymbery AJ, Thompson RCA. The role of companion animails in the emergence of parasitic zoonoses. Int J Parasitol 2000; 30: 1369-1377.

Scaini CJ, Toledo RN, Lovatel R, Dionello MA, Gatti FA, Susin L, et al. Contaminação ambiental por ovos e larvas de helmintos em fezes de cães na área central do Balneário Cassino, Rio Grande do Sul. Rev Soc Bras Med Trop 2003; 36(5): 617-619. PMid:14576878.

Souza BMPS. Epidemiologia da Ehrlichia sp. e avaliação do seu potencial zoonótico no município de Salvador, Bahia [Dissertação]. Salvador: Escola de Medicina Veterinária, Universidade Federal da Bahia; 2008.

Xavier GA. Prevalência de endoparasitos em cáes de companhia em Pelotas-RS e risco zoonótico [Monografia]. Pelotas: Instituto de Biologia da Universidade Federal de Pelotas; 2006. 